\title{
Deceptive Advertising and Consumer Reaction: A Study of Delta Soap Advertisement
}

\author{
Raymond Chimezie Ukaegbu \\ Managing Director/CEO of Supreme Events, Port Harcourt City, Nigeria \\ Email: raymondukaegbu@gmail.com
}

How to cite this paper: Ukaegbu, R.C. (2020) Deceptive Advertising and Consumer Reaction: A Study of Delta Soap Advertisement. Open Access Library Journal, 7: e5865. https://doi.org/10.4236/oalib.1105865

Received: October 17, 2019

Accepted: March 8, 2020

Published: March 11, 2020

Copyright $\odot 2020$ by author(s) and Open Access Library Inc.

This work is licensed under the Creative Commons Attribution International License (CC BY 4.0).

http://creativecommons.org/licenses/by/4.0/

\section{(c) (i) Open Access}

\begin{abstract}
Deceptive advertisement is one of the conventional approaches that unethical business organizations seek to increase their product demand. Deceptive advertisement through the media has been on the rise, which is detrimental to both the companies and the consumers. The researcher ran a survey using the case of Delta Soap advertisement to assess how it influences consumer demand and organization reputation. There was a unanimous agreement from the study participants that false marketing strategies negatively affect business sales in the long term and diminish consumer trust. Most consumers eventually become aware of businesses that use deceptive marketing techniques and ultimately avoid purchasing such products.
\end{abstract}

\section{Subject Areas}

Economics

\section{Keywords}

Marketing Communication, Advertising, Deceptive Advertising, Consumer Reaction, Misleading Commercials

\section{Introduction}

\subsection{Background Information}

Deceptive marketing is false or misleading sales activities and information aimed at luring, coercing, seducing, persuading, or enticing both potential and existing consumers of a product to patronize a trader, sellers or manufacturers of a product in [1]. It is an act of selling the concept as the sole aim is geared towards the immediate conversion of goods to cash, not minding the aftermath effect it may have on the buyer or consumer as well as the organization's sales, sustenance, and growth potentials in [2]. It can be perpetrated through personal sell- 
ing, advertising, labeling packaging, catalog, and deceptive telemarketing. However, in the developed countries of the world such as America and Europe and even in some under-developed countries, deceptive marketing activities are criminal offenses under the Competition Act. Also, the Act governs various deceptive marketing practices, unsupported test claims and testimonials, misleading ordinary price claims, sending deceptive prize notices by mail or e-mail, certain types of multi-level marketing systems, and misleading advertising in [3]. Specific provisions also supplement the Criminal Code rules regarding promotional contests.

Customers are day after day affected by advertising and marketing. Customers should be conscious that their buying behavior can be misled through advertising methods. They have to be aware of the way companies present and advertise their products or service in [4]. After explaining in detail what deceptive advertising is, the research study shows that customers can react in different ways and how they do it. Moreover, how they judge their purchase and their opinions of the company that deceived them, as well as how they express themselves nowadays.

\subsection{Analysis of Deceptive Marketing in the Soap Industry}

The soap industry may be one of the key leaders in deceptive advertisement messages. There are concerns on whether stainless looking beauty queens featured on the commercials of soaps use the soap daily on their skin, or it could be a mere deceit to lure unsuspecting members of the public in [5]. There's a need for complete mass orientation and reorientation of our traders and producers, right from the small scale traders and producers to the big time traders and producers, because they exhibit a lot of selfish marketing traits and attitudes in [6].

Every product or services have its own advantage or disadvantage, but what they also do is to emphasize the product's merits and de-emphasize its demerits. So they need a complete reorientation and reorganization of their attitudes to life and moral value system. It is a big problem and barrier to our nation's economic growth as this equally affects our image internationally in [6]. The situation has gone so harmful to the extent that even the regulatory bodies such as the Standard Organizations of Nigeria (SON), Advertising Practitioners' Council of Nigeria (APCON) and Consumer Protection Council are more or less like toothless bulldogs as consumers are left at the mercy of the nefarious marketing activities of manufacturers, advert media houses and traders in our markets. This unchecked unethical marketing activities that is ravaging the nation's moral commercial value system leaves one wondering about the roles of the relevant regulatory bodies in [6]. The word "Caveat Emptor" is almost becoming the order of the day as consumers have to look over their shoulders when making purchases. However, the long run chain reaction of these nefarious acts boils down to post-purchase dissonance of such product, lack of repeat purchase and low sales, leading to the failure of such product in the market and subsequently 
leading to waste of enormous amount of money, time and other material resources invested into the production of such products [7]. The overall effect on the nation will be the closure of such productive outfit and mass retrenchment of workers, which could also trigger off social vices as the retrenched workers must keep body and soul together.

\subsection{Study Objectives}

1) identify the advertising suggestible to deception

2) examine consumers' reaction to Delta soap Advertisement

3) identify the product in which the seller commonly deceived buyers

\subsection{Study Questions}

1) What kind of advertising is suggestible to deception?

2) What are consumers' reactions to Delta soap advertisements?

3) Which of the product does seller commonly deceived buyers

\section{Literature Review/Theory}

\section{Analysis of the Social Judgment Theory}

Social judgment theory suggests that knowing a person's attitudes on subjects can provide you with clues about how to approach a persuasive effort. Created by Sherif and associates, the theory focuses on peoples' assessment of compelling messages in [8] [9]. Research using this theory has often focused on cognitive processes, but there are numerous implications for communicators seeking to persuade others. Social judgment theory proposes that people make evaluations (judgments) about the content of messages based on their anchors, or stance, on a particular topic message in [10]. In addition to an individual's anchor, each person's attitudes can be placed into three categories. First, there is the latitude of acceptance, which includes all those ideas that a person finds acceptable. Second, there is the latitude of rejection, which provides for all those ideas that a person finds unacceptable. Finally, there is the latitude of non-commitment, which includes plans for which you have no opinion you neither accept nor reject these ideas. The literature and much empirical evidence hold that the advertisers and their advocates are engaged rigorously in the three types of deception when creating product awareness [11]. In most settings, the ability to measure deceptive advertisements requires a more detailed assessment of the incidence information (on ads, product quality, and inventories), which is challenging to conduct when using a survey [12]. Deception is a general phenomenon that can occur in virtually any form of communication under the conflict of interest in [13]. Deception comes in a wide array of forms other than the outright lie, and among the features that differentiate them, are the amount and sufficiency of information, degree of truthfulness, clarity, relevance, and intent [13]. Whatever the type of deception, it causes several ethical questions and issues for companies, consumers, and policymakers. 
Apart from addressing the serious issue of unusual sales drop and or new product failure in the market that could be occasioned by post-purchase dissonance and lack of repeat purchase by the consumer as a result of the nefarious acts of deceptive advertising, it will be of great importance to traders in our various markets and the management of companies as suggestions will be given to the policymakers which also will serve as clues towards improving their marketing policies and programs towards maintaining and wooing both existing and potential consumers respectively in [1]. Besides, it will be useful to other organizations, industries, and governmental agencies in the area of policy formulation and strategic marketing. Deceptive advertising is an advertisement or marketing practice, which is considered misleading if there is a "representation, omission, or practice that is likely to mislead the consumer" in [2].

The advertisement does not only necessarily have to cause actual deception, but as noted by the Federal Trade Commission (FTC, 1998), the act will likely mislead the consumer.

Although the immense ventures and endeavors have been observed on deceptive advertising, which includes identifying and measuring deception but a very narrow focus is given on its effects on consumer loyalty. Deceptive advertising is so to speak as the use of fake or misleading statements in publicity in [2]. The misleading advertisement has been around since the inauguration of time and is still prevalent today. Sometimes it is done innocently by an advocate; however, it is done with the intent in the direction of deceiving the consumers in [3]. Generally, it is perceived that deception in advertising (false claims) leads to first purchase by the consumer, tricked by the false claims made by the marketer but eventually after the first use the consumer realizes the real quality/value of the product/service in most cases. This realization of fallacy hinders the customer from being loyal to that particular brand in [14].

Some traders in the Nigerian markets, as well as some producers of various consumer goods, engage in deceiving buyers and consumers to patronize their products by lying about what their product(s) cannot do in [11]. This they achieve in the course of their selling activities with the consumer or through advertising messages, labeling of product packages, and in handbills.

\section{Methodology}

The collection of information in this study used a survey method. This is because it facilitates face-to-face contact between the researcher and the respondents in [9].

Hence, the cross-sectional survey method was adopted for the study. The survey was in the form of a questionnaire which was created to collect data from the users of Delta Soap regarding their usage pattern and influence of advertising on the patronage, repeat purchase and loyalty, perception of deception in ads, and the effects of lying on their preference of the products. Convenience based non-probability sampling was used to collect data from 155 participants using a personal survey method. The study was carried out in Yaba, Oshodi, and Alaba 
International market areas in Lagos State. Two factors informed the selection of these areas. The first factor is the heterogeneous nature of these localities and their extensive commercial activities. Besides, they are composed of a multi-ethnic settlement harboring a significant number of diverse interest commercial groups. These locations also house the most modern broader markets called Tejuosho, Oshodi, and Alaba International market, respectively, where a variety of goods and commercial activities take place. As such, they afford the researcher the opportunity of examining the subject matters among the different commercial and international markets. The second factor is that these areas are an urban settlement. They, therefore, serve as a good representation of urban centers in the country for investigating the subject matter, Deceptive Advertising.

\section{Results/Discussions}

Research question 1: What kind of advertising is suggestible to deception? (Figure 1)

Research question 2: What is the consumers' reaction to Delta soap advertising (Figure 2)

Research question 3: Which of the product do seller commonly deceived buyers? (Table 1)

Table 1. Product in which the seller commonly deceived buyers.

\begin{tabular}{ccc}
\hline Product & Frequency & Percent \\
\hline Household items & 14 & $9.0 \%$ \\
Drugs & 89 & $57.4 \%$ \\
Wear & 12 & $7.7 \%$ \\
Electronics & 10 & $6.5 \%$ \\
Beverages & 11 & $7.1 \%$ \\
Services & 9 & $5.8 \%$ \\
Others & 10 & $6.5 \%$ \\
Total & 155 & 100.0
\end{tabular}

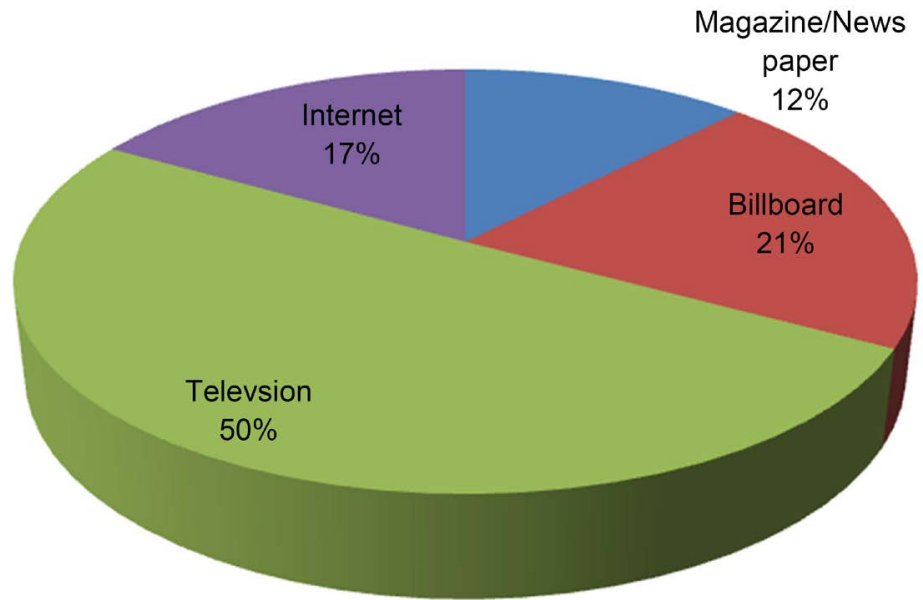

Figure 1. Advertising suggestible to deception. 


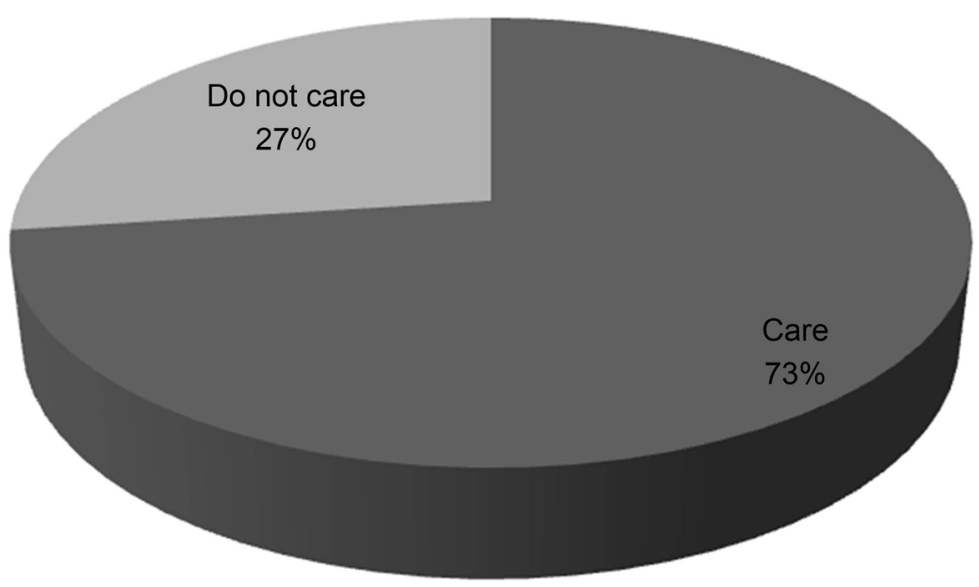

Figure 2. Reaction to Delta soap advertising.

\section{Conclusion and Recommendations}

The findings revealed that the most suggestible type of advertising was on television. The nowadays society is always in direct contact with television. Television brings information about news, entertainment but also advertisements. It is impossible to watch television without experiencing an advertisement. This type of communication allows touching a maximum number of people using mass marketing techniques. Also, a few persons do not find it easy to identify whether an advertisement is deceptive. Moreover, criteria such as age and gender were not relevant to our research. Concerning the primary consumers' reactions, the majority of people care about deceptive advertising. The interesting point was that people who stated they do not care about deceiving advertising do not buy the brand products anymore. Thus, it proves that, in one sense, they care about the advertising technique. The results of this study can be beneficial for companies that would like to deceive their customers, thanks to advertisements. The study concluded that deceptive advertising affects a business demand and customer loyalty negatively in the long term.

\section{Conflicts of Interest}

The author declares no conflicts of interest regarding the publication of this paper.

\section{References}

[1] Cawley, J., Avery, R. and Eisenberg, M. (2011) The Effect of Advertising and Deceptive Advertising on Consumption: The Case of Over-the-Counter Weight Loss Products.

[2] Iqbal, S. and Siddiqui, D.A. (2019) The Impact of Deceptive Advertising on Customer Loyalty: A Case of Telecommunication Industry in Karachi, Pakistan. International Journal of Industrial Marketing, 4, 39-69.

https://doi.org/10.5296/ijim.v4i1.14607

[3] Misra, S. (2015) Deceptive Political Advertising: Some New Dimensions. Journal of Legal, Ethical and Regulatory Issues, 18, 71. 
[4] Boush, D.M., Friestad, M. and Wright, P. (2015) Deception in the Marketplace: The Psychology of Deceptive Persuasion and Consumer Self-Protection. Routledge, London. https://doi.org/10.4324/9780203805527

[5] Akpan, U.U., Nda, I. and Nkenta, I.P. (2015) Testimonials in Television Advertising and Consumer Patronage of Select Antiseptic Products in Uyo Urban, Akwa Ibom State of Nigeria. International Journal of Education and Research, 3, 217-236.

[6] Onuorah, J.E. (2017) Imperatives of Advertising Regulation. International Journal of Communication: An Interdisciplinary Journal of Communication Studies, 20, No. 1.

[7] Kumar, S. (2019) Status of Deceptive Advertising Practices in India: 2015-2017. IIMS Journal of Management Science, 10, 64-81. https://doi.org/10.5958/0976-173X.2019.00005.8

[8] Bajaj, S. (2017) Regulation of Advertisement for Food Products in India: Advertisement for Food Products. In: Food Safety in the 21 st Century, Academic Press, London, 469-477. https://doi.org/10.1016/B978-0-12-801773-9.00038-8

[9] Aghakhani, H. and Main, K.J. (2019) Can Two Negatives Make a Positive? Social Exclusion Prevents Carryover Effects from Deceptive Advertising. Journal of Retailing and Consumer Services, 47, 206-214. https://doi.org/10.1016/j.jretconser.2018.11.021

[10] Ramos Salazar, L. (2017) Changing Resistant Audience Attitudes Using Social Judgment Theory's “Anchor” Point Perspectives. Communication Teacher, 31, 90-93. https://doi.org/10.1080/17404622.2017.1285412

[11] Krafft, J. and Saito, R. (2015) Greenwashing an Experimental Study about the Effects of Misleading and Deceptive Environmental Claims in Advertising.

[12] Teng, S., Khong, K.W. and Goh, W.W. (2015) Persuasive Communication: A Study of Major Attitude-Behavior Theories in a Social Media Context. Journal of Internet Commerce, 14, 42-64. https://doi.org/10.1080/15332861.2015.1006515

[13] Mathiyazhagan, T. and Nandan, D. (2010) Survey Research Method. Media Mimansa, 4, 34-45.

[14] Xie, G.X. and Boush, D.M. (2011) How Susceptible Are Consumers to Deceptive Advertising Claims? A Retrospective Looks at the Experimental Research Literature. The Marketing Review, 11, 293-314. https://doi.org/10.1362/146934711X589480 